\section{FINAL DISPOSAL OF REFUSE IN AMERICAN CITIES.}

BY RUDOLPI HERING.

The burning of garbage has been practised in Amerien for some 20 vears, the first furnace being ereeted on Gouvernors Island, New York, in $\mathbf{1 8 8 5}$, by Lieut. Riley. In 1887 the first municipal furnnce was built in Des IJloines, Ia., and was called the Engle crematory. It had a large horizontal grate upon which the garbage was delivered from the top, to be first dried, then partially burned by a coal or oi fire kept going at one end, and finally completely burned together with the fumes at the other end of the furnace and then discharged up the ehimucy. About ten such furnaces are still in use. 'The best example of the Engle furnace was at the C'licago World's Fair in 1893, where the refuse was destroyed by natural gas. Another furnace was introduced in 1803, and is known as the Dixon crematory. 'The hest example was at the St. Lonis World's Fair in 1904. The first mumicipal Dixon furnace was built in Ellwood. Ind. At present there are about 40 in use. In design it is very similar to the Engle crematory, but there were improvements for ridding the garbage of some of its moisturo and other minor advantages. As the largo amount of moisture in the garbage was the clief oljection to any method of incinerition, several crematories were proposed to give a better preliminary drying. The most successful of these was the Decarie furnace, brought out in 1901. The first mumicipal plant was erected in Vlinneapolis. This furnace receives the garbage in a crato which is suspended over the fire, and thereby effects the preliminary drying. In order to make the furnnee moro durable than any of those previously built, water jackets of steel were used. The disadvantage of such jucketing is the keeping down of the temperature in the furnace by the comparatively low temperature necessitated by the water jacket.

Redisetion, another method of garbage disposal, has been developed during the last 20 yeurs, und is practised only because Ameriean garbuge yields about 3 per cent. of a superior grease which fetches from two to four cents a pound. Where are two methods of extrneting greuse one introdueed by Yerz in Buffalo about 1885, involving the use of naphthn, where after separating the solution and the water from the tankage by pressure, the solution is cooled to regain the naphtha, leaving the grense to be barreled for sule. The other, introduced later by Arnold, is more economicnl, and involves cooking the garbage with stenm, which separntes it into three parts, tankinge, water and grease. The latter two are sepmated from the tankage by pressure. and the grense is separated from the water by gravity. T'his process is now curried on in most large cities by private enterprise, except in Clevclund, Ohio, where there is a mumicipul reduction plant.

The separntion of grease and water from the tankage by pressure is not always perfect, and the jesidual greaso lowers the value of the tankage as a fertilizer. 'Therofore, so long as the price of gremse is high, it lats been found economical to treat the tankage subserquently with nuphtha to extract the remnining greise.

Rubbish.-Rubbish is still, oven in Now York City, to n large extent used for filling up vacunt ground, in objectionable method on sanitury grounds. In a few of the larger cities the rubbish is hurned, before which it is usunlly picked over for anything valuablo, in a building which also serves for an incinerator, and the heat is utilised for various purposes.

tshes.-Ashes collected separately are unobjectionable for filling in low ground, and for roud making.

Sireel sucepings.-Sweepings from eities not only lanvo nunurial value, but they can also often be burnt in. an incinerator.

There is at present no city in the United Stutes where all the city refuse is mixed and properly incinornted. There is one incinerator at work nt Westmount, Cimuda, and ono has just been completed at West Blighton, Borough of Richmond, where mixed refuse will bo incinernted. Therc has not existed in Amoricn tho sume necessity for destroying it, as more land las been available for dumping. Further, the larger quantities of grense found in Americun garbage has developed an industiy which was not practic. nble in Europe. This industry separated garbage from the rest of the refuse and denlt with it, but did not dispose of the remainder. Tho value of ashes when mixed with gnrbage consisted in its contents of unburned conl remain. ing, which in Europe effectively burns the mixture. When not mixed with garbage it could be dumped for filling. Rubbish also burns itself very rendily. Ashes and rubbish have therefore been mixed only where their fuel value was required to assist the burning if garbage.

Analysis of the refuse and recogni'ion. of the necessity for evaporating the wnter contained in the greater quntity of garbage per expita than in Europe, shows that complete incineration of refuse should be obtained in Ameriean cities without addition of fuel. September i: the only doubtful month, owing to the large constumption of fruit. though no positive evidence exists that even then fuel must be added.

Another difference between America and Europe, is the use of anthracite conl, which has more fine ash, whicn tends to obstruct the necessary draught and retards ombustion. (iiven garlonge with more water, moto combustible refuse, and conl with more ash, it remains to be seen what effect these differences with have on the burning of mixed refuse in America. Incineration properly worked may be carried on in the midst of cities, as abundantly evidenced in Europe; and, though the cost of such inc neration may exced that of other methods. yet, it may be more econonical than " clieaper disposal at a greater d stance. Even in New York etlicient incinera. tion nt numerous points along the bast and Hudson ruvers, with short hnuls, may prove both economicnl and satisfactory.

\section{THE FINA DISPOSITION OF CITY REFUSE BY MIXED REFUSE DES'TRUCIION, AND 'THE FINAL DISPOSIYION OF REFUSE IN GREA'T BRI'IAIN.}

BY J. T. HETHELSTON, ASSOC. M. AM. SUC. C.E.

In 1006, about 8,000,000 cubic yards of waste, consisting of ashes, garbage, rubbish and st reet sweepings were collected in Greater Now York. Wach inhabitant of tho city contributed on an avernge ubout 1470 pounds of refuse per annum, aceording to a recent report by Mlessrs. Parsons, Hering und Whinery. About $30 \%$ of this rofuse contains organic matter, mainly found in the garbage and street sweepings. 'lo collect und dispose of this muss of materinl without crenting $n$ nuisance and with $n$ reasonable degree of economy is a problen, the difticulties of which are now being apprecinted in the United States. The orgunic mutter in the waste is the main source of trouble from the sanitary standpoint. 'I'he transmission of disenso from infected wistes to food, by means of the common house.fly, hus recently received some attention, and in the future it is quite possible that further investigations concerning flies as carriers of disease germs, may have an important bearing on the choice between sejentific methods

Quantities of Dirferent Classias of Refuse.
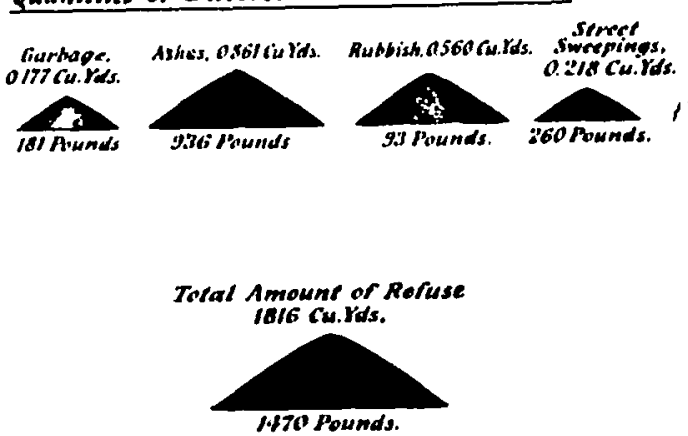

Fra. 1.

Comparative Diagram showing amount of rofuso removod per person, per year, in Now York City. 
of waste disposnl. The vnlue of the classes of refuse shown on Fig. 1 consists of the grease and fortilizer or tankage from the garbage; the unburned coal in the ashes; the saleable paper, rubber, lenther, etc. sorted from the rubbish, and the fertilizing material in the street sweepings. All four classes nre more or less combustible. If the saleable parts, in the proportions shown by the diagram, were recovered, their value would be about s1.00 for the $1470 \mathrm{lb}$. of refuse, while the fuel value of the combustible in tho mixed wastes is about the same. Generally spenking, it will cost more to recover the valuable portions of the refuse than the material is worth, if all classes of the waste nre treated in a sanitary mnnner.

Between 1805 and 1904, garbage cremation was practised in Richmond Borough, while the ashes, rubbish, and atreet sweepings with some garbage were used for filling lowlands. The system in use leing deemed umsa tisfactory. a representative district was selected and a mechanical annlysis made of houselold refuse covering a period of one year. Street sweepings were eliminated from the problem, as their treatment was left for future considera. tion. A hout $108,000 \mathrm{lb}$. of ashes and rubbish and 28,000 pounds of garbage were mechnnically separated into the classes shown on Fig. 2. Garbage was low in Februnry
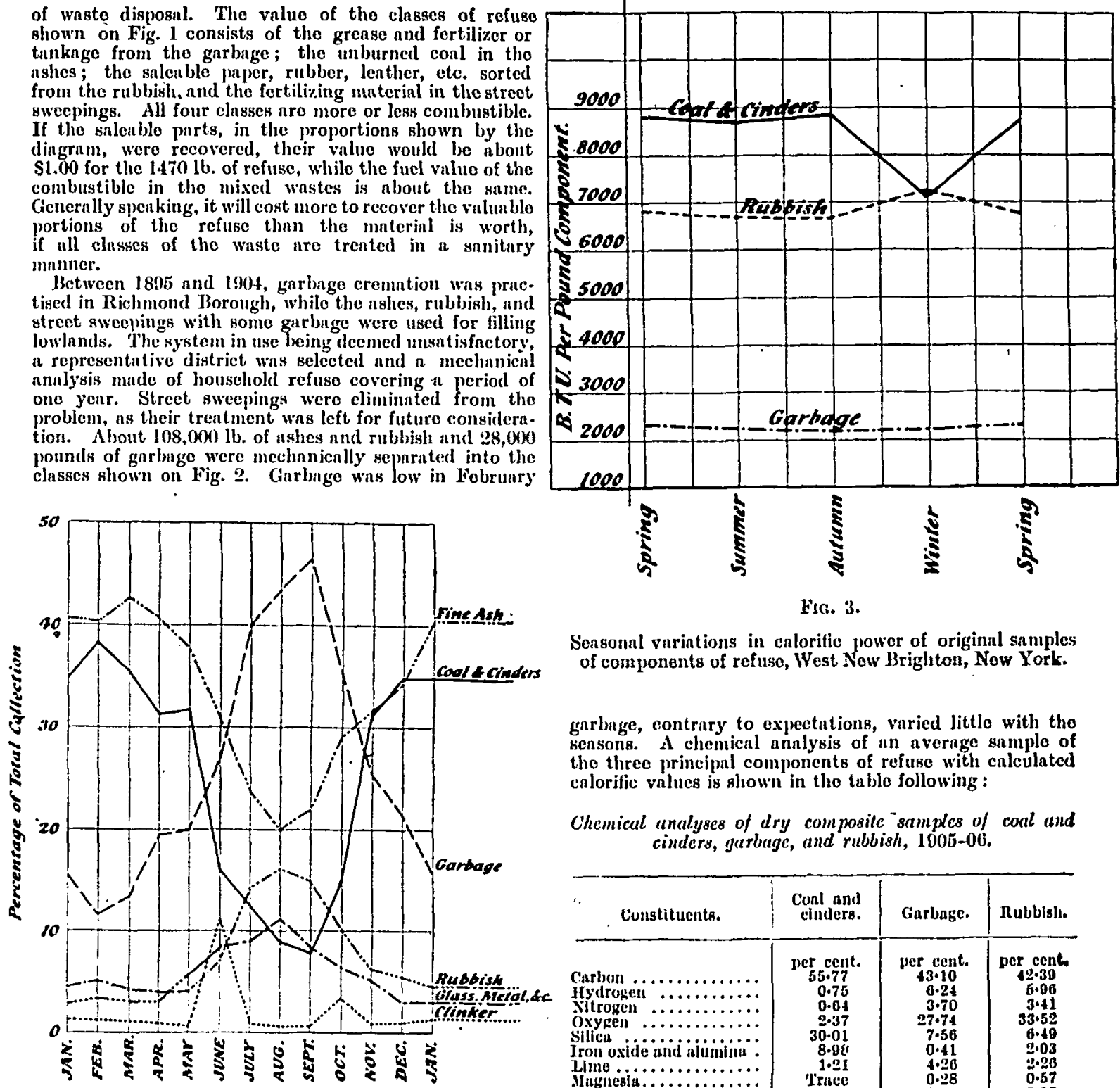

Fic. 3.

Seasonal variations in calorific power of original samples of components of refuso, West Now Brighton, Now York.

garbage, contrary to expectations, varied littlo with tho seasons. $A$ chentical analysis of an average sample of the three principal components of refuse with calculated calorific values is shown in the table following:

Chemical analyses of dry composile samples of conl and cinders, garbage, and rubbish, 1005-06.

\begin{tabular}{|c|c|c|c|}
\hline Constituents. & $\begin{array}{l}\text { Cunl and } \\
\text { cinders. }\end{array}$ & Garbage. & Rubbish. \\
\hline 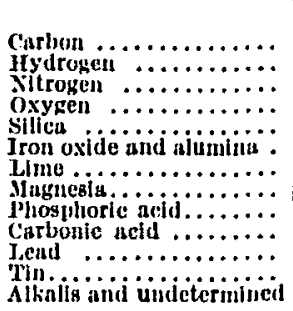 & 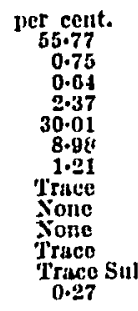 & 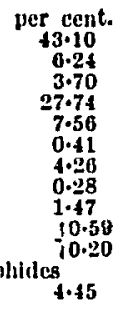 & $\begin{array}{c}\text { per cent. } \\
42 \cdot 30 \\
5.96 \\
3.41 \\
33.52 \\
6.49 \\
2.03 \\
2.26 \\
0.57 \\
0.10 \\
1.40 \\
0.52 \\
\text { Traco } \\
1.21\end{array}$ \\
\hline
\end{tabular}

Diagtam showing monthly varintions by woight in components of houschold refuso, West Now brighton District.

and high in Soptemher, while " eonl mol einders" varied inversely, and the "fine ush" would parnllel the "conl and ejinders"; rubbish was low in winter and high in summer. The seasonal variations of the varions components of refuso shown in Fig. 2 indicate that September will bo the criticnl month of tho yenr in self combustion of the household waster in tho locality considered. Sa mples were tukeu of the different compronents from the meehanien? amalysis, and calorific tests with proximate analyses numbering 104 determinations were mude at the Lederlo Laboratories and by Mr. J3. F. Welton, at the Laboratory of the Commissioners of Aecounts, Now York City, so ns to determino avernge heat values nnd sensonal variations in the enlorifio powers of the components. 'J'lue lient units por pound originnl of the three muin divisions of household refuse from this district are riven in Fig. 3 . "l'te drop in the heat value of "conl and cinder's " und the rise in rubbish, during the winter woro ruther surperising, whilo

Culorific culues in British thermal units.

\begin{tabular}{|c|c|c|}
\hline $\begin{array}{c}\text { Calculated from above } \\
\text { minjyses } \ldots \ldots \ldots \ldots \text { ! }\end{array}$ & 8,382 & 7,070 \\
\hline $\begin{array}{l}\text { Werage of ca } \\
\text { determinnt }\end{array}$ & 8,510 & 8,351 \\
\hline
\end{tabular}

The calculations from tho malyses aro mado as follows $02,100\left(\mathrm{H}-\frac{\mathrm{O}}{8}\right)+1.4,500 \quad \mathrm{C} .=$ British thermal units. The analyses wero made by Professor S. F. Pecklham. Aided by the ealorimetor tests, jroximnte analyses, and mechanical sepurations, a basis was provided for the compritations shown in the firkt two divisions of Fig. 4. As might be oxpected, nsh is high in winter and the wator content of houschold refuse increases with the proportion of gitrbnge in summer. Tho second division of the diagram gives the seatonal varintions in the heat units por pound of mixed household refuse. Again tho summer 


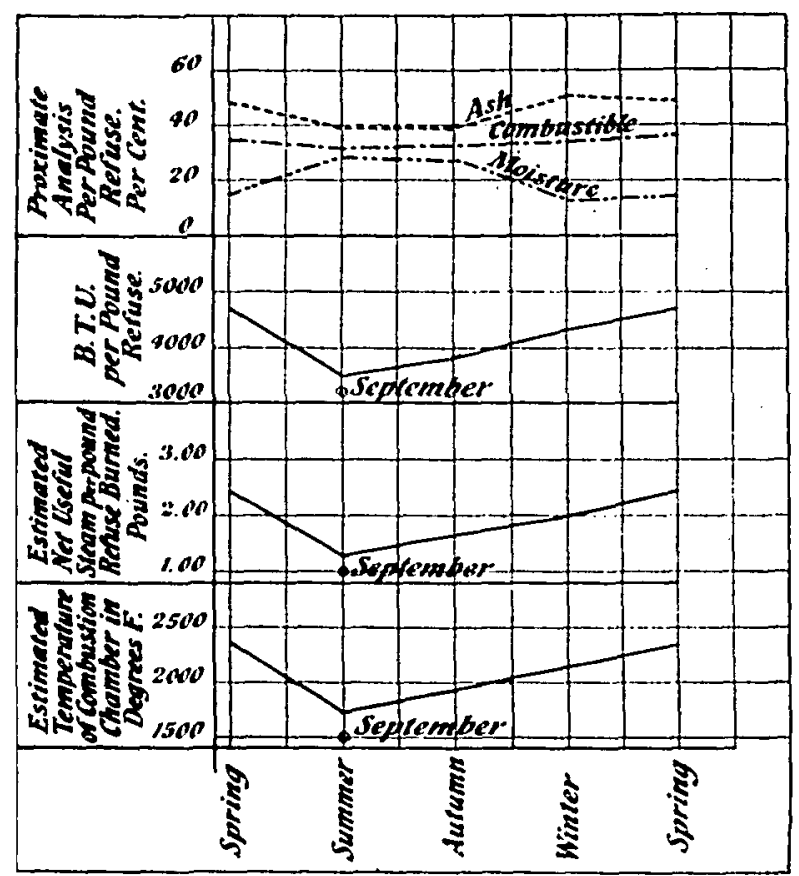

Fio. 4.

Mixed refuse destruction. Sensonal variations, West Now Irighton, New lork.

refuse is low in culorific power, and September is shown to be the critical time for burning the mixed waste, as a lurge umount of moisture then tends to lower tempera. tures and renders the crention of nuisanees from unconnumed gases likely. An estimate of the netunl power to be expected from the burning of household refuse in Richmond, based upon the foregoing summnry, in con. junction. with a number of small-size practical experiments in destroying the waste by the aid of forced dranght, indientes that ench pound of matrinl will evaporate $j$ it own weight of water during the worst month of tho yenr (September), while it mny he expected that the evaporation will run over $2 \mathrm{lb}$. of water during the season when refuse is in the most favorable condition for burning. The foregoing estimutes were made on the basis of 1 modern refuse destructor speciully designed for conditions in $\mathrm{Rich}$ mond and efficiently operated. 'The question of temperatures in the self combustion of refuse contuining organic matter detemines to a grent extent the possibility of destroving the waste without crenting a nuisunce from the esenpe of obnoxions gases. Below $1250^{\circ} \mathrm{F}$. hydrocurbons aro not generally dissocinted. Very high degrees of hent on the other hund result in " grently incrensed cost of furnace muintenunce. It is desira ble to keep the tempern. tures as stendy as possible. Temperatures between $1800^{\circ}$ to $2(10)^{\circ} \mathrm{F}$, are best suited to present dny furmaces. The "1pproximute hent of the gnses resulting from the destruction of mixed household refuse in Richmond, as shown in Fig. 4, indicute that even during September temperatures should be sufficiently ubove the dauger point to prevent the esen po of olorous guses.

As a result of the varions experimonts and tests mude in tho Borotigh of Riehmond, mixed refuse destruction of houschold wastes was reconmended as best suited to the local conditions, and a furmuce has been erected ut West New lirighton from tests of which nctunl data of practical value will soon be available.

After it was decided to adopt the British mothod of buning mixed houseloold refuse, tho writer was commissioned by the President of the Burough of Richmond to oxamino und report on 1 number of British rofuse destructors in netual operntion. Forty plants were visited, thirty+nine of which wero in (Arent Britnin and ono in Conadu. Rofuso in Grent Mritnin and Jrolnnd is durk in appearunce, due to the soft toul ash, and there is, apparently, less rubbish, less garbage, more ashes and more moisture in the materinl than in mixed refuso found in the vicinity of New York. T'he summer refuso Irom Now York contains a large proportion of combustiblo muterial. The British householder throws awny only about one-hilf the refuse that the arernge houscholder in New York does. In Great Brituin it costs two to three times moro to collect and remove the material than it does to dispose of it. 'The system of collection is directly dependent upon the method of disposal adopted. A type of wagon used in Great Brituin for collecting mixed refuse is constructed of wood, holds ahout three cubic yards of muterinl, and enn be dumped by means of a crunk and serew. Another type nims at proventing the escaje of dust when the cart is being loaded by means of a wooden cover and side wings. Where gurbage is collected separately, it is necessary to provide the cart or wagon with a tight body of the kind common in New York City. Such curts are made of ateel and ure satis. factory where garbage reduction or garbage cremation systems are in operation. If, however, mixed refuse is to be economicully collected, the larger the whron tho less frequent will bo the trijes to the place of disposill. Such a wagon is of the bottom dump variety and is provided with a canvas cover dividing the open top into four sections, so that when collecting, from onc-half to three-quarters of the wngon may always remain covered, and thus, to a grent extent, prevent the escupe of dust from ushes in windy wenther.

As the cost of collection is such an important factor, a plant should be as near as possible to the centre of the district served. British destructors are often plnced right in the henrt of the city. A plant at Rathmines, near Dublin, Ireland, is quite near the Town Hall. Tho refuse burned at this place furnishes power for an outyut of 300 k.w. No odours or muisances were upparent, Most of the plants inspected in Great. Britain wero working well in the centro of towns. Shorediteh has a refuso destructor surrounded on practically all sides by higher buildings, which lats been working for over ten yeurs, and wonld have been elosed long ago if it were a musance. Some of the power produced at this destructor is used for electric lighting. At Batley, near leeds, the refuso destruet or is located near the electric power station, and furnishes sten to run $n$ portion of the power plant. Besides the combination of refuse destruct or with electric: generating stations, stenm power developed by burning the muterial is used for various other purposes such as pumping sewage, water, and works purposes, or the light ing of the destructor depots, and furnishing power for various municipal uses. It is stated that the power generated at a combination refuse destruetor and sewage pumping stution at Worthing, near Brighton, saves the municipality "bout $\$ 800$ to $\$ 1000$ per annum in fuel bills. At. Swansen power from refuse is used for genernting electric current to operute ubout 41 miles of street ruilway.

Besides the stenm genernted from refuse, uhout onothird of the original naterial remains on the grate in tho form of elinker. If elinker lus been bumed hard, it will replace broken stone or gravel and sand ns an aggregato for concrote. Crushed, sorted, and mixed with venent it ean bo made into brioks and pavement sinbs. Bricks of good guality uro made nt Woulwieh from eement and clinker by subjecting the mixture to a henvy pressure. Power at this plant is uned for elest rie lighting.

This briof review indicates to some extent the scientitic possibilities involved in $n$ considerntion of tho ynestion. It ought to be borne in mind, however, that ntilisation is a secondary consideration, and that tho primary object shouk be to ripidly remove and timally disposo of the muterials in a sanitury manner.

\section{THE DESTRUCIION OF WASTIE IN JPULIC INSTITUTIONS AND PRIVATE BUILDINCBS.}

\section{H. WhLAM $\%$, Moltse.}

'The grentest advances in tho past ten yents in mothods fon the disposal of sity whate have been mato not hy the municipul anthorities of Now York, but by public instilutions ned preat business corporations. Ihis 